\title{
Bioactive compounds and enzymatic activity in minimally processed eggplant packedunderactive modified atmosphere
}

\section{Compostos bioativos e atividade enzimáticaem berinjela minimamente processada embaladaem atmosfera modificada ativa}

\author{
Flávia Aparecida de Carvalho Mariano-Nasser ${ }^{1}$; Cristine Vanz Borges²; \\ Juliana Arruda Ramos ${ }^{3}$; Mauricio Dominguez Nasser ${ }^{4 *}$; \\ Giovanna Alencar Lundgren ${ }^{5}$; Karina Aparecida Furlaneto ${ }^{6}$; \\ Tânia Regina Kovalski ${ }^{7}$; Rogério Lopes Vieites ${ }^{8}$
}

\begin{abstract}
The study aimed to assess bioactive compounds and polyphenoloxidase activity of minimally processed eggplants stored in different atmospheres. Eggplants (Solanum melongena L.; cv. Ciça) were minimally processed (MP), sanitized and treated with a $2 \%$ citric acid solution. They were packed in plastic containers (vacuum) of nylon + transparent polyethylene and submitted to modified atmospheres with the following concentrations of gases: control (atmospheric air), vacuum, $4 \% \mathrm{O}_{2}+5 \% \mathrm{CO}_{2}, 4 \%$ $\mathrm{O}_{2}+6 \% \mathrm{CO}_{2}, 4 \% \mathrm{O}_{2}+7 \% \mathrm{CO}_{2}$, and $4 \% \mathrm{O}_{2}+8 \% \mathrm{CO}_{2}$, being stored in a cold chamber $\left(5 \pm 1{ }^{\circ} \mathrm{C}\right.$ and $90 \pm 1 \%$ relative humidity) for 10 days. The analyses consisted of the total phenolic compounds, total antioxidant activity, flavonoids, and polyphenoloxidase activity. The experimental design was a completely randomized design in a $6 \times 6$ factorial scheme (treatment vs. storage period). The data were submitted to analysis of variance and a regression analysis was performed for storage time. The active modified atmosphere with $8 \% \mathrm{CO}_{2}$ is effective in reducing the polyphenoloxidase activity in minimally processed eggplant. The contents of phenolic compounds and flavonoids of minimally processed eggplant decrease with storage.
\end{abstract}

Key words: Storage. Bioactive compounds. Polyphenoloxidase. Solanum melongena L.

1 Pesquisadora, Pós-doutoranda, Departamento de Horticultura, Faculdade de Ciências Agronômicas, Universidade Estadual Paulista, UNESP, Botucatu, SP, Brasil. E-mail: flaviamariano1@hotmail.com;

2 Discente, Curso de Doutorado, Programa ade Pós-Graduação em Horticultura, Departamento de Horticultura, Faculdade de Ciências Agronômicas, UNESP, Botucatu, SP, Brasil. E-mail: cristine.vanzb@gmail.com

$3 \mathrm{Dr}^{\mathrm{a}}$ em Energia na Agricultura, Departamento de Horticultura, Faculdade de Ciências Agronômicas, UNESP, Botucatu, SP, Brasil. E-mail: ju.a.ramos@globo.com

4 Pesquisador Científico, Agência Paulista de Tecnologia dos Agronegócios, APTA, Polo Regional Alta Paulista, Adamantina, SP, Brasil. E-mail: mdnasser@apta.sp.gov.br

5 Discente, Curso de Doutorado. Programa ade Pós-Graduação em Ciências da Nutrição, Universidade Federal da Paraíba, UFPB, João Pessoa, PB, Brasil. E-mail: giolundgren@gmail.com

6 Discente do Curso de Doutorado, Programa de Pós-Graduação em Energia na Agricultura, Departamento de Horticultura, Faculdade de Ciências Agronômicas, UNESP, Botucatu, SP, Brasil. E-mail: karina_furlaneto@globo.com

7 Mestre em Horticultura, Departamento de Horticultura, Faculdade de Ciências Agronômicas, UNESP, Botucatu, SP, Brasil. E-mail: tania kovalski@yahoo.com.br

8 Prof. Titular, Departamento de Horticultura, Faculdade de Ciências Agronômicas, UNESP, Botucatu, SP, Brasil. E-mail: vieites@ fca.unesp.br

Author for correspondence 


\title{
Resumo
}

\begin{abstract}
Objetivou-se avaliar os conteúdos de compostos bioativos e atividade da polifenoloxidase durante o armazenamento de berinjelas minimamente processadas acondicionadas em diferentes atmosferas. As berinjelas (Solanum melongena L.) cv. Ciça foram minimamente processadas (MP), higienizadas e tratadas com solução a $2 \%$ ácido cítrico. Foram acondicionadas em embalagens plásticas (vácuo) de nylon + polietileno transparente, e em seguida submetidas à modificação da atmosfera com a aplicação das seguintes concentrações de gases: controle (ar atmosférico), vácuo, $4 \% \mathrm{O}_{2}+5 \% \mathrm{CO}_{2}$, $4 \% \mathrm{O}_{2}+6 \% \mathrm{CO}_{2}, 4 \% \mathrm{O}_{2}+7 \% \mathrm{CO}_{2}$ e $4 \% \mathrm{O}_{2}+8 \% \mathrm{CO}_{2}$ e armazenadas em câmara fria $\left(5 \pm 1^{\circ} \mathrm{C}\right.$ e $90 \pm 1 \%$ de umidade relativa) por 10 dias. As análises realizadas foram: compostos fenólicos totais, atividade antioxidante total, flavonoides e atividade da polifenoloxidase. O delineamento experimental utilizado foi inteiramente casualizado (DIC), em esquema fatorial 6 × 6 (tratamento x período de armazenamento). Os dados foram submetidos à análise de variância e fez-se regressão para as análises no tempo de armazenamento. Atmosfera modificada ativa com $8 \% \mathrm{CO}_{2}$ é eficaz em reduzir a atividade da polifenoloxidase em berinjela minimamente processada. Os conteúdos de compostos fenólicos e flavonoides da berinjela minimamente processada diminuem com o armazenamento.
\end{abstract}

Palavras-chave: Armazenamento. Compostos bioativos. Polifenoloxidase. Solanum melongena L.

\section{Introduction}

Fruits and vegetables have a variety of bioactive compounds that provide many health benefits, including activation of immune defenses and reduction of inflammatory responses (LANDETE, 2012). Eggplant (Solanum melongena L.) is a fruit consumed worldwide and commonly grown in subtropical and tropical regions. It originated in India and was introduced to Brazil by the Portuguese in the 16th century (RIBEIRO et al., 2007). Small farmers have grown this crop in the majority of Brazilian region (FINCO et al., 2009).

Eggplant is considered a good source of minerals and vitamins, in addition to being rich in fiber and low in lipids. The interest in this vegetable has been growing rapidly because it is a good source of antioxidants, such as anthocyanins and phenolic acids, which are beneficial to human health (GAJEWSKI et al., 2009). Eggplant phenolic compounds have the potential to reduce intestinal glucose uptake and provide cell antioxidant protection, preventing the oxidation and complications of diabetes, and the flavonoids present in this vegetable have been attributed to a reduction of plasma lipids (SUDHEESH et al., 1999; CHEREM et al., 2007).
Despite the antioxidant benefits of phenolic compounds to human health, it is important to recognize that a high phenolic acid content has some disadvantages for the industry, such as an accelerated browning of fruits in the minimum processing (TAN et al., 2016). Mechanical stresses caused by processing increase the rate of biochemical reactions responsible for changes in color, taste, texture, and nutritional quality of minimally processed products (ROCHA et al., 2003). In addition, the exposure of minimally processed products to low $\mathrm{O}_{2}$ levels and very high $\mathrm{CO}_{2}$ levels can lead to anaerobic respiration and fermentation, with the production of undesirable metabolites and the occurrence of physiological disorders, such as enzymatic browning, decreasing product quality (GHIDELLI; PEREZ-GAGO, 2018). The enzymatic browning of eggplant fruit pulp is caused by the action of polyphenoloxidases (PPOs), which catalyze the conversion of phenolic acids (stored in vacuoles) into quinones, which react with oxygen to give rise to brown color compounds, causing a decrease in quality of the final product (KAUSHIK et al., 2017). Therefore, the $\mathrm{O}_{2}$ and $\mathrm{CO}_{2}$ range in the package, as well as the handling and/or processing characteristics, should be well defined to maintain quality and nutritional value in minimally processed eggplants. 
Thus, the aim of this study was to assess the contents of bioactive compounds and enzymatic activity during storage of minimally processed eggplants stored in different atmospheres.

\section{Material and Methods}

Eggplants (cv. Ciça) were harvested at the commercial maturation stage from a farm located in Campinas, SP (Brazil). These fruits were transported to the Laboratory of Post-Harvest of Fruits and Vegetables, School of Agronomic Sciences, UNESP, in Botucatu (SP), where they were selected for physical and biological integrity. Afterwards, the fruits were washed in running water to remove dirt from harvest and transportation and immersed in a sodium hypochlorite solution $(200$ $\mathrm{mgL}^{-1}$ ) for 20 minutes.

The fruits were cut into $1.5 \mathrm{~cm}$ thick slices and the inedible parts (piece of fruit next to the peduncle) were removed. The slices received $50 \mathrm{mg} \mathrm{L}^{-1}$ sodium hypochlorite solution for 20 minutes. The solution was discarded and the slices were washed in running water. After this process, the slices were immersed in $2 \%$ citric acid solution for 10 minutes to avoid their browning. The drainage was carried out in a domestic drainer and finished in a domestic centrifuge $\left(\mathrm{Consul}^{\circledR}\right)$ at a rotation of $2800 \mathrm{rpm}$ for 40 seconds.

Samples of $150 \mathrm{~g}$ were conditioned in plastic containers (vacuum) of nylon + transparent polyethylene of high oxygen barrier $\left(10 \mathrm{~cm}^{3}\right.$ day $\left.^{-1}\right)$ and water vapor $\left(5 \mathrm{~m}^{2}\right.$ day $\left.^{-1}\right)$, and then submitted to modified atmosphere treatments with the following concentrations of gases: Treatment 1, atmospheric air; Treatment 2, vacuum; Treatment 3, 4\% $\mathrm{O}_{2}+5 \% \mathrm{CO}_{2}$; Treatment 4, 4\% $\mathrm{O}_{2}+6 \%$ $\mathrm{CO}_{2}$; Treatment 5, 4\% $\mathrm{O}_{2}+7 \% \mathrm{CO}_{2}$; and Treatment $6,4 \% \mathrm{O}_{2}+8 \% \mathrm{CO}_{2}$. The packages were kept for 10 days in a cold chamber with a temperature of 5 $\pm 1{ }^{\circ} \mathrm{C}$ and a relative humidity of $90 \pm 1 \%$. Every 2 days, three replications from each treatment were analyzed for the total antioxidant activity, total extractable phenolic compounds, flavonoids, and polyphenoloxidase activity.

A pre-test was performed in order to find the best extractor (ethyl alcohol and acetone) for the analysis of phenolic compounds of the minimally processed eggplant. The best extraction was observed in $80 \%$ ethyl alcohol, with the extract obtained from 1 g of eggplant pulp and $10 \mathrm{~mL}$ of the extractor (ethyl alcohol 80\%). The mixture was homogenized in Turrax and then in an ultrasonic bath for 15 minutes, being centrifuged at $6000 \mathrm{rpm}$ at $4{ }^{\circ} \mathrm{C}$ and for 20 minutes. The supernatant was removed with an automatic pipette and stored in an amber flask at 8 ${ }^{\circ} \mathrm{C}$ until the beginning of the biochemical analyses.

To determine the total extractable phenolic compounds, the spectrophotometric method described by Singleton et al. (1999) was used, in which $0.5 \mathrm{~mL}$ of extract was mixed in $2.5 \mathrm{~mL}$ of Folin-Ciocalteau solution (20\%), standing for 5 minutes and then $2.0 \mathrm{~mL}$ of sodium carbonate (4\%) was added. The reaction was conditioned at ambient temperature and in the dark for 120 minutes. The absorbance was measured at $740 \mathrm{~nm}$ by using gallic acid as a standard and the results were expressed as mg of gallic acid $100 \mathrm{~g}^{-1}$ of pulp.

The total antioxidant activity was assessed by the DPPH (2,2-diphenyl-1-picrylhydrazyl)method, as the methodology described by Mensor et al. (2001), in which $3 \mathrm{~mL}$ of ethyl alcohol (80\%), 0.5 $\mathrm{mL}$ of ethylic extract, and $0.3 \mathrm{~mL}$ of DPPH solution (prepared in ethyl alcohol PA)was added to a test tube and the reaction was incubated in the dark for 45 minutes. The reading was performed at $517 \mathrm{~nm}$ and the results were expressed as the ability to scavenge the radical in $\%$.

The polyphenoloxidase enzyme activity (EC: 1.10.3.1) was determined following the Kar and Mishra (1976) methodology with adaptations. The extract was made with $0.2 \mathrm{~g}$ of the sample and $5 \mathrm{~mL}$ of the sodium phosphate buffer $\mathrm{pH} 6.0$ (after testing with different buffers and $\mathrm{pH}$ ), being homogenized in a Turraxe and centrifuged at $6000 \mathrm{rpm}$ at $4{ }^{\circ} \mathrm{C}$ for 
25 minutes. The supernatant was removed with an automatic pipette and placed in an amber glass. The reaction was performed with $0.3 \mathrm{~mL}$ of extract and $1.85 \mathrm{~mL}$ of $0.1 \mathrm{M}$ catechol solution (prepared with a buffer solution $\mathrm{pH} 6.0$ ), being water bathed at 30 ${ }^{\circ} \mathrm{C}$ for 30 minutes and added $0.8 \mathrm{~mL}$ of perchloric acid at the end to stop the reaction. The reading was performed at $395 \mathrm{~nm}$ after absorption spectrum scanning and the results expressed in $\mu \mathrm{mol}$ catechol transformed into $\min ^{-1} \mathrm{~g}^{-1}$ fresh mass.

The quantification of flavonoid contents followed the recommendations of Santos and Blatt (1998) and Awad et al. (2000). For this, $4 \mathrm{~mL}$ of acidified methanol was added in a $0.2 \mathrm{~g}$ of eggplant sample, followed by an ultrasonic bath for 30 minutes. The sample was removed from the bath and $1 \mathrm{~mL}$ of $5 \%$ aluminum chloride solution (w/v)in methanol was added. Subsequently, the sample was incubated for 30 minutes and centrifuged for 20 minutes at 6000 rpm. The supernatant was removed and read in a spectrophotometer at an absorbance of $425 \mathrm{~nm}$. The values were expressed as $\mathrm{mg}$ in quercetin equivalent $100 \mathrm{~g}^{-1}$ of pulp.

The experimental design was a completely randomized design in a $6 \times 6$ factorial scheme (treatment $\times$ storage period). The data were submitted to analysis of variance and the means compared by the Tukey's test at 5\%significance level. The regression analysis was performed for analyzing the storage time.

\section{Results and Discussion}

The total phenolic compounds in eggplant extracts were assessed by the Folin method and the results are shown in Figure 1. The values of total phenolic compounds initially found in eggplants cv. Ciça were high (73.8 mg of gallic acid $100 \mathrm{~g}^{-1}$ ) when compared to several other eggplant cultivars (KAUR et al., 2014). These compounds are found in many fruits and vegetables and their identification reveals important information regarding food quality and potential health benefits (antioxidant and antitumor activity) (DU et al., 2009; WANG et al., 2011). In eggplants, this action mechanism of phenolic compounds plays an important role in reducing lipid oxidation in plant and animal tissues. When incorporated into human food, it not only preserves food quality (color, taste, and odor) but also reduces risks of developing pathologies such as atherosclerosis and cancer (NAYANATHARA et al., 2016).

Figure 1. Contents of total extractable phenolic compounds (mg of gallic acid $100 \mathrm{~g}^{-1}$ ) in minimally processed eggplant over a 10-daystorage at $5 \pm 1{ }^{\circ} \mathrm{C}$ and $90 \pm 1 \%$ RH. Botucatu, 2015.

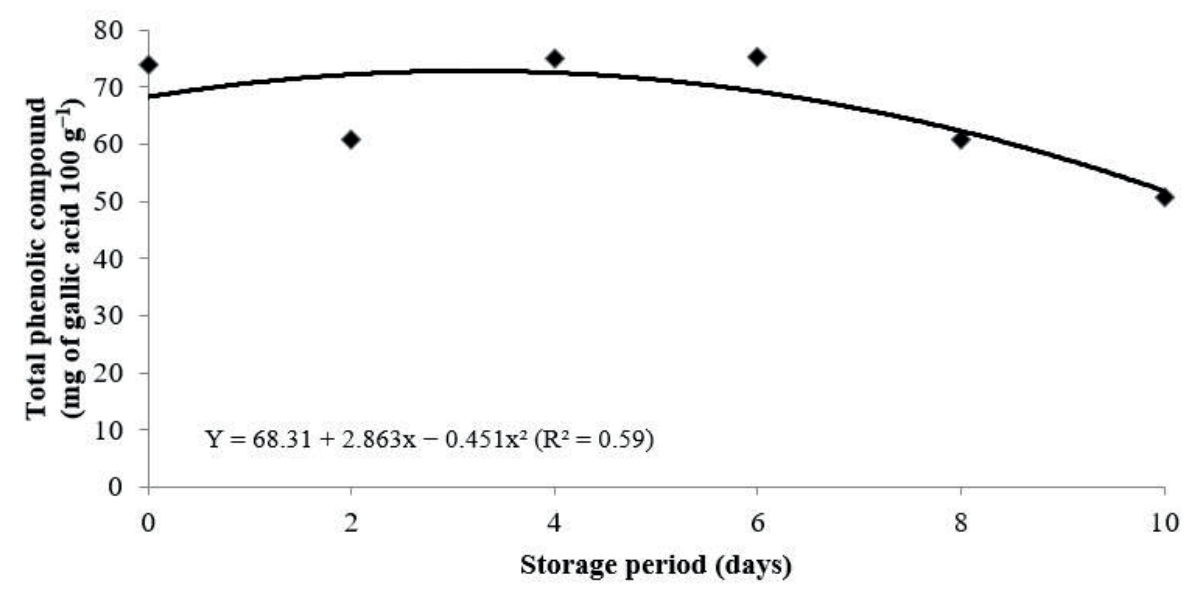


The content of phenolic compounds increased until the fourth day of storage (Figure 1), decreasing after this period and reaching the final value of $50.7 \mathrm{mg}$ of gallic acid $100 \mathrm{~g}^{-1}$. This behavior was similar in all gas concentrations, with no interaction effect between treatments and storage period. In minimally processed plants, injuries in the plant tissue caused by cutting the fruits and/or vegetables lead to an increase of respiratory rate and ethylene production, causing a stimulus to the formation of secondary metabolites, which are produced as a plant defense mechanism (ALARCÓN-FLORES et al., 2015; KLUGE et al., 2006), and may increase the functional food value. In addition, the biosynthesis of phenolic compounds may continue after harvest and increase during storage at low temperatures (CONCELLÓN et al., 2007; HOLCROFT et al., 1998) and modified atmosphere (SELCUK; ERKAN, 2015).

Concellón et al. (2007) described changes in the contents of phenolic compounds of eggplants stored at a low temperature $\left(0\right.$ and $\left.10{ }^{\circ} \mathrm{C}\right)$ and reported a decrease in their levels at the end of storage. According to Lee et al. (2003), a prolonged storage may promote chemical and enzymatic oxidation of phenolic compounds, contributing to their reduction. The increase of enzymatic activity catalyzes oxidation and hydroxylation reactions of some phenolic compounds (phenols and catechols) into quinones and then in melanin, which is no longer characterized as phenolic compounds (ZIYAN; PEKYARDIMCI, 2003; SERRADELL et al., 2000). Such a loss of phenolic compounds may also be related to their function in acting against reactive oxygen species, which could be produced during storage.

The antioxidant activity of eggplant extracts at the end of storage decreased by about 30\% (Figure 2 ), regardless of the used gas concentrations (atmospheric air, vacuum, 4\% $\mathrm{O}_{2}+5 \% \mathrm{CO}_{2}, 4 \%$ $\mathrm{O}_{2}+6 \% \mathrm{CO}_{2}, 4 \% \mathrm{O}_{2}+7 \% \mathrm{CO}_{2}$, and $4 \% \mathrm{O}_{2}+8 \%$ $\left.\mathrm{CO}_{2}\right)$. Ayhan and Esturk (2009) also reported an increase in the antioxidant activity of pomegranate under modified atmosphere (up to the 9th day of storage), followed by a reduction over time. This decrease in the antioxidant activity from the fourth day of storage probably occurred due to a decrease in the phenolic compounds, which are mainly responsible for the antioxidant properties of eggplants (YAMASAKI et al., 1997; SELCUK; ERKAN, 2015). The antioxidant capacity and the content of phenolic compounds have a high positive correlation in eggplant fruits. These compounds have a high reducing power and possibly play an important role as antioxidants and regulators of the redox state of cells. In vitro experiments show that phenolic compounds can eliminate free radicals present in cells (GÜRBÜZ et al., 2018).

Figure 2. Total antioxidant activity (\%) measured by the DPPH method in minimally processed eggplant over a 10day storage at $5 \pm 1{ }^{\circ} \mathrm{C}$ and $90 \pm 1 \% \mathrm{RH}$. Botucatu, 2015.

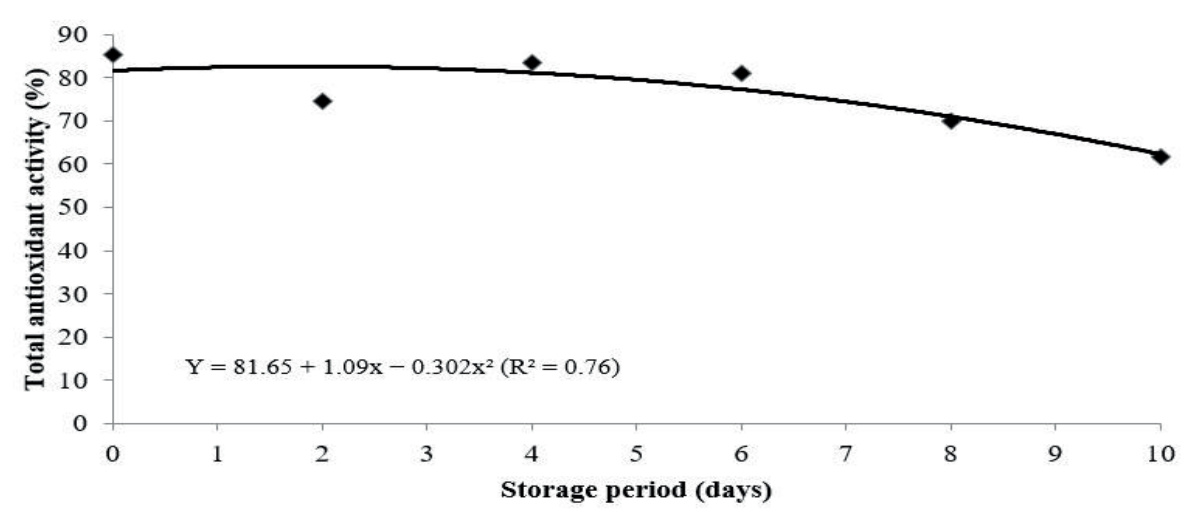


In this study, flavonoid contents of 1.4 to 3.04 $\mathrm{mg}$ in quercetin equivalent $100 \mathrm{~g}^{-1}$ were observed in minimally processed eggplants packed in different modified atmospheres. Xiang-Min et al. (2014) observed higher values (about $50 \mathrm{mg}$ in quercetin equivalent $100 \mathrm{~g}^{-1}$ ) in intact eggplant fruits. The authors identified four different flavonoids (quercetin, apigenin, kaempferol, and isorhamnetin) in leaves and fruits of eggplant. Fategbe et al. (2013) reported contents of flavonoids in eggplant pulp from 70 to $150 \mathrm{mg}$ in quercetin equivalent $100 \mathrm{~g}^{-1}$.
A decrease in flavonoid contents from 2.89 to $2.13 \mathrm{mg}$ in quercetin equivalent $100 \mathrm{~g}^{-1}$ was observed during the storage period (Figure 3), probably due to an increase in the enzymatic activity during processing (cutting). According to Matheis (1983), the polyphenoloxidase (PPO) oxidizes phenolic compounds into quinones in the presence of oxygen, forming brown or black pigments. An increase in the enzymatic activity of PPO of minimally processed eggplants was observed up to the sixth day of storage at all $\mathrm{CO}_{2}$ concentrations (Figure 4), except for $8 \%$, reinforcing the hypothesis of oxidation of phenolic compounds by the enzyme.

Figure 3. Flavonoid contents ( $\mathrm{mg}$ in quercetin equivalent $100 \mathrm{~g}^{-1}$ ) in minimally processed eggplant over a 10 -day storage at $5 \pm 1{ }^{\circ} \mathrm{C}$ and $90 \pm 1 \% \mathrm{RH}$. Botucatu, 2015.

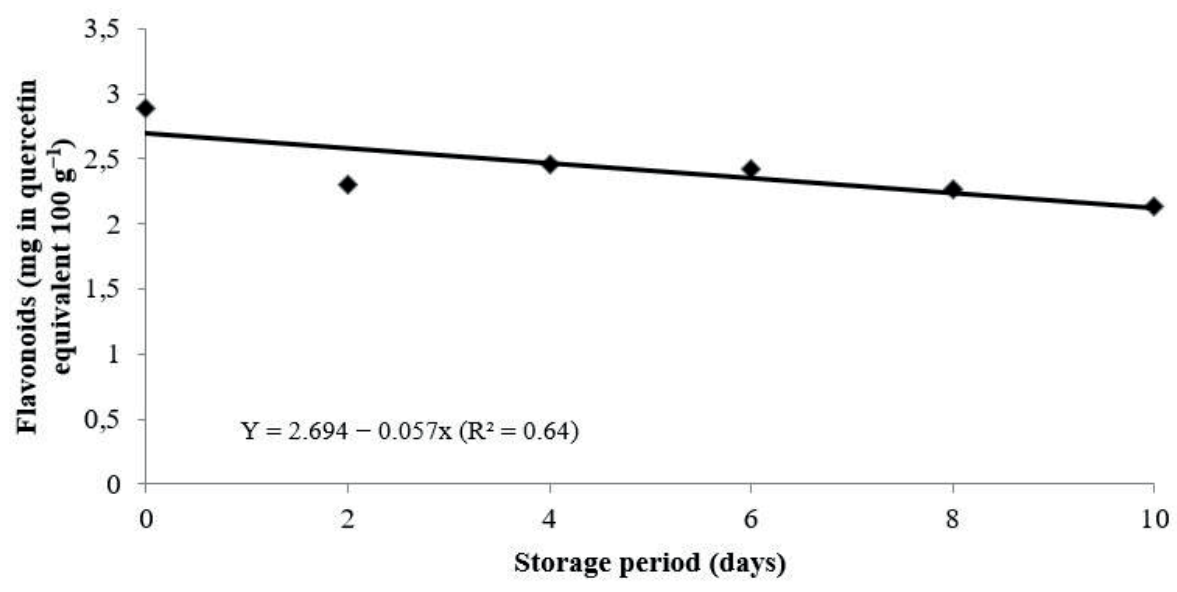

Figure 4. Polyphenoloxidase activity ( $\mu \mathrm{mol}$ catechol transformed into $\mathrm{min}^{-1} \mathrm{~g}^{-1}$ fresh mass) in minimally processed eggplant in different modified atmospheres over a 10-day storage at $5 \pm 1{ }^{\circ} \mathrm{C}$ and $90 \pm 1 \%$ RH. Botucatu, 2015.

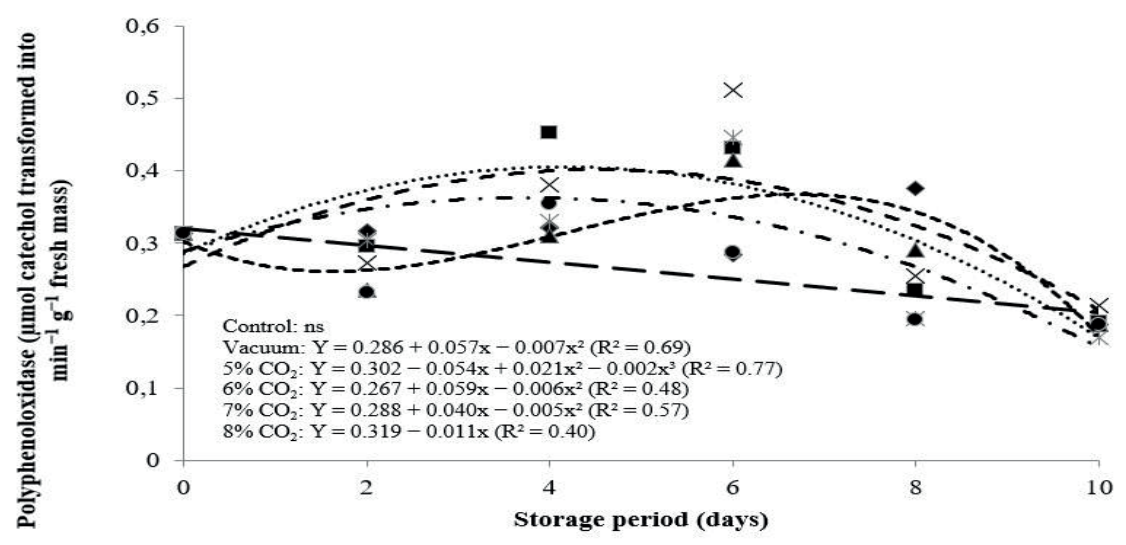


The activity of the enzyme polyphenoloxidase increased during the storage period between the fourth and sixth day (Figure 4), except in the control treatment and $8 \% \mathrm{CO}_{2}$, and after the sixth day, the activity presented a decrease. After eggplant cutting, there is an increase in the contact surface with oxygen and a tendency to increase the polyphenoloxidase (GASULL; BECERRA, 2006), resulting in the browning of the eggplants.

The change in the atmosphere with an increase in $\mathrm{CO}_{2}$ concentration and a decrease in $\mathrm{O}_{2}$ of minimally processed products can cause a decrease in the respiratory rate and ethylene production, with a consequent inhibition or reduction of the enzymatic activity (e.g. polyphenoloxidase), avoiding postharvest deterioration by physiological disorders (MORAES et al., 2008; CHITARRA; CHITARRA, 2005).However, this behavior was not observed in our study with minimally processed eggplant because the control did not change over the storage period, but presented a descending linear behavior with $8 \% \mathrm{CO}_{2}$, reducing the polyphenoloxidase activity over the storage period (10 days)and showing to be effective in its control when compared to the other treatments.

The minimally processed eggplant packed in vacuum presented by the fourth day of storage the highest enzyme activity when compared to other active modified atmospheres, probably in response to the initial processing of the product. Snoeck et al. (2011) observed an increase in the enzymatic activity by the third day in vacuumpacked processed potatoes, suggesting that the cutting of the plant tissue may have induced the polyphenoloxidase synthesis occurring at the beginning of storage. The reduction of activity from the third day (vacuum) may have occurred due to a low oxygen concentration in the atmosphere. In minimally processed 'Ágata' potatoes, the vacuum was the most effective method to control browning by the enzymatic action when compared to other gas concentrations (PINELI et al., 2005).

\section{Conclusions}

The active modified atmosphere with $8 \% \mathrm{CO}_{2}$ is effective in reducing the polyphenoloxidase activity in minimally processed eggplant.

The contents of phenolic compounds and flavonoids of the minimally processed eggplant decrease with storage.

\section{References}

ALARCÓN-FLORES, M. I.; ROMERO-GONZÁLEZ, R.; VIDA, J. L. M.; FRENICH, A. G. Systematic study of the content of phytochemicals in fresh and fresh-cut vegetables. Antioxidants, Switzerland, v. 4, n. 2, p. 345$358,2015$.

AWAD, A. M.; JAGER, A.; WESTING, L. M. Flavonoid and chlorogenic acid levels in apple fruit: characterization of variation. Scientia Horticulturae, Mission, v. 83, n. 3, p. 249-263, 2000.

AYHAN, Z.; ESTURK, O. Overall quality and shelf life of minimally processed and modified atmosphere packaged ready-to-eat pomegranate arils. Journal Food Science, Chicago, v. 74, n. 5, p. 399-405, 2009.

CHEREM, A. R.; TRAMONTE, V. L. C. G.; FETT, R.; DOKKUM, W. Efeito da casca da berinjela (Solanum melongena) sobre as concentrações plasmáticas de triglicerídeos, colesterol total e frações lipídicas, em cobaias (Cavia porcellus) hiperlipidêmicos. Revista Brasileira de Plantas Medicinais, Botucatu, v. 9, n. 1, p. 51-65, 2007.

CHITARRA, M. I. F.; CHITARRA, A. B. Pós-colheita de frutos e hortaliças: fisiologia e manuseio. 2. ed. Lavras: UFLA, 2005. $785 \mathrm{p}$.

CONCEllón, A.; AÑón, M. A.; ChaVes, A. R. Effect of low temperature storage on physical and physiological characteristics of eggplant fruit (Solanum melongena L.). LWT-Food Science and Technology, Zürich, v. 40, n. 3, p. 389-396, 2007.

DU, G.; LI, M.; MA, F.; LIANG, D. Antioxidant capacity and the relationship with polyphenol and vitamin $\mathrm{C}$ in Actinidia fruits. Food Chemistry, Barking, v. 113, n. 2, p. 557-562, 2009.

FATEGBE, M. A.; IBUKUN, E. O.; KADE, I. J.; ROCHA, B. T. A comparative study on ripe and unripe eggplant (Solanum melongena) as dietary antioxidant sources. Journal of Medicinal Plants Research, Nsukka, v. 7, n. 6, p. 209-218, 2013. 
FINCO, A. M.; BEZERRA, J. R.; RIGO, M.; CÓRDOVA, K. R. Elaboração de biscoitos com adição de farinha de berinjela. Revista Brasileira de Tecnologia Agroindustrial, Ponta Grossa, v. 3, n. 1, p. 49-59, 2009.

GAJEWSKI, M.; KATARZYNA, K.; BAJER, M. The influence of postharvest storage on quality characteristics of fruit of eggplant cultivars. Notula e Botanica e Horti Agrobotanic i Cluj-Napoca, Cluj-Napoca, v. 37, n. 2, p. 200-205, 2009.

GASULL, E.; BECERRA, D. Caracterización de polifenoloxidase extraída de pêra (cv. Packam's Triumph) y manzana (cv. Red Delicious). Información Tecnológica, La Serena, v. 17, n. 6, p. 69-74, 2006.

GHIDELLI, C.; PÉREZ-GAGO, M. B. Recent advances in modified atmosphere packaging and edible coatings to maintain quality of fresh-cut fruits and vegetables. Critical Reviews in Food Science and Nutrition, Cleaveland, v. 58, n. 4, p. 662-679, 2018.

GÜRBÜZ, N.; ULUISIK, S.; FRARY, A.; FRARY A.; DOĞANLAR, S. Health benefits and bioactive compounds of eggplant. Food Chemistry, Barking, v. 268 , n. 1, p. 602-610, 2018

HOLCROFT, D. M.; GIL, M. I.; KADER, A. A. Effect of carbon dioxide anthocyanins, phenylalanine ammonia lyase and glucosyltransferase in the arils of stored pomegranates. Journal of American Society of the Horticulture and Science, Alexandria, v. 123, n. 1, p. 136-140, 1998.

KAR, M.; MISHRA, D. Catalase, peroxidase, and polyphenoloxidase activities during rice leaf senescence. Plant Physiology, Rockville, v. 57, n. 1, p. 315-319, 1976.

KAUR, C.; NAGAL, S.; NISHAD, J.; KUMAR, R.; SARIKA. Evaluating eggplant (Solanum melongena L) genotypes for bioactive properties: a chemometric approach. Food Research International, Barking, v. 60, p. 205-211, 2014.

KAUSHIK, P.; GRAMAZIO, P.; VILANOVA, S.; RAIGÓN, M. D.; PROHENS, J.; PLAZAS, M. Phenolics content, fruit flesh colourand browning in cultivated eggplant, wild relatives and interspecific hybrids and implications for fruit quality breeding. Food Research International, Barking, v. 102, p. 392-401, 2017.

KLUGE, R. A.; COSTA, C. A.; VITTI, M. C. D.; ONGARELLI, M. G.; JACOMINO, A. P.; MORETTI, C. L. Armazenamento refrigerado de beterraba minimamente processada em diferentes tipos de corte. Ciência Rural, Santa Maria, v. 36, n. 1, p. 263-270, 2006.

LANDETE, J. M. Updated knowledge about polyphenols: functions, bioavailability, metabolism, and health. Critical Reviews in Food Science and Nutrition, Cleveland, v. 52, n. 10, p. 936-948, 2012.

LEE, K. W.; KIM, Y. J.; KIM, D. O.; LEE, H. J.; LEE, C. Y. Major phenolics in apple and their contribution to the total antioxidant capacity. Journal of Agricultural and Food Chemistry, Munich, v. 51, n. 22, p. 6516-6520, 2003.

MATHEIS, G. Enzymatic browning of foods: quantitative relationships between browning and food constituents. Zeitschriftfür Lebensmittel-Untersuchung und-Forschung, Berlin, v. 176, n. 6, p. 454-462, 1983.

MENSOR, L. L.; MENEZES, F. S.; LEITÃO, G. G.; REIS, A. S.; SANTOS, T. C.; COUBE, C. S.; LEITÃO, S. G. Screening of Brazilian plant extracts for antioxidant activity by the use of DPPH free radical method. Phytotherapy Research, Chichester, v. 15, n. 2, p. 127130, 2001.

MORAES, I. V. M.; CENCI, S. A.; BENEDETTI, B. C.; MAMEDE, A. M. G. N.; SOARES, A. G.; BARBOZA, H. T. G. Características físicas e químicas de morango processado minimamente e conservado sob refrigeração e atmosfera controlada. Ciência e Tecnologia de Alimentos, Campinas, v. 28, n. 2, p. 274-281, 2008.

NAYANATHARA, A. R.; MATHEWS, A.; AALOLAM, K. P.; RESHMA, J. K. Evaluation of total phenol, flavonoid and anthocyanins content in different varieties of eggplant. Emergent Life Science Research, Kanpur, v. 2, n. 2, p. 63-65, 2016.

PINELI, L. L. O.; MORETTI, C. L.; ALMEIDA, G. C.; ONUKI, A. C. A.; NASCIMENTO, A. B. A. Caracterização química e física de batatas Ágata minimamente processadas, embaladas sob diferentes atmosferas modificadas ativas. Pesquisa Agropecuária Brasileira, Brasília, v. 40, n. 10, p. 1035-1041, 2005.

RIBEIRO, C. S. C.; BRUNE, S.; REIFSCHNEIDER, F. J. B. Berinjela (Solanum melongena L.). Brasília: EMBRAPA Hortaliças. Sistemas de Produção, 2007. Disponível em: <http://sistemasdeproducão.cnptia. embrapa.br/FontesHTML/Beringela/Beringela Solanum_melongena_L/index.html $>$. Acesso em: $1 \overline{5}$ ago. $201 \overline{7}$.

ROCHA, A. M. C. N.; COULON, E. C.; MORAIS, A. M. M. B. Effects of vacuum packaging on the physical quality of minimally processed potatoes. Food Service Technology, New York, v. 3, n. 2, p. 81-88, 2003.

SANTOS, M. D.; BLATT, C. T. T. Teor de flavonoides e fenóis totais em folhas de Pyrostegia venusta Miers de mata e de cerrado. Revista Brasileira de Botânica, São Paulo, v. 21, n. 2, p. 135-140, 1998. 
SELCUK, N.; ERKAN, M. Changes in phenolic compounds and antioxidant activity of sour-sweet pomegranates cv. Hicaznar during long-term storage under modified atmosphere packaging. Postharvest Biology and Technology, Amsterdam, v. 109, n. 1, p. 3039, 2015.

SERRADELL, M.A.; ROZENFELD, P. A.; MARTINÉZ, G. A.; CIVELlO, P. M.; CHAVES, A. R.; AÑON, M. C. Polyphenoloxidase activity from strawberry fruit (Fragaria ananassa, Duch., cv Selva): characterization and purification. Journal of the Science of Food and Agriculture, London, v. 80, n. 9, p. 1421-1427, 2000.

SINGLETON, V. L.; ORTHOFER, R.; LAMUELARAVENTÓS, R. M. Analysis of total phenols and other oxidation substrates and antioxidants by means of FolinCiocalteau reagent. Methods of Enzymology, New York, v. 299, n. 1, p. 152-178, 1999.

SNOECK, D.; RAPOSO, M. F. J.; MORAIS, A. M. M. B. Polyphenoloxidase activity and colour changes of peeled potato (cv. Monalisa) in vacuum. International Journal of Postharvest Technology and Innovation, Geneve, v. 2, n. 3, p. 233-242, 2011.

SUDHEESH, S.; SANDHYA, C.; KOSHY, S.; VIJAYALASKSHMI, N. R. Antioxidant activity of flavonoids from Solanum melongena. Phytotherapy Research, Chichester, v. 13, n. 5, p. 393-396, 1999.

TAN, S. P.; KHA, T. C.; PARKS, S. E.; ROACH, P. D. Bitter melon (Momordica charantia L.) bioactive composition and health benefits: a review. Food Reviews International, London, v. 32, n. 2, p. 181-202, 2016.

WANG, S.; MELNYK, J. P.; TSAO, R.; MARCONE, M. F. How natural dietary antioxidants in fruits, vegetables and legumes promote vascular health. Food Research International, Essex, v. 44, n. 1, p. 14-2, 2011.

XIANG-MIN, P.; JONG-WOOK, C.; GI-NA, L.; JUNGRO, L.; GYU-TAEK, C.; HO-SUN, L.; KYUNG-HO, M.; JING, G.; HONG, S. K.; SOK-YOUNG, L. Variation in antioxidant activity and flavonoid aglycones in eggplant (Solanum melongena L.) germplasm. Plant Breeding Biotechnology, Suwon, v. 2, n. 4, p. 96-403, 2014.

YAMASAKI, H.; SAKIHAMA, Y.; IKEHARA, N. Flavonoid-peroxidase reaction as a detoxification mechanism of plant cells against $\mathrm{H}_{2} \mathrm{O}_{2}$. Plant Physiology, Glasgow, v. 115, n. 4, p. 1405-1412, 1997.

ZIYAN, E.; PEKYARDIMCI, S. Characterization of polyphenoloxidase from Jerusalem artichoke (Helianthus tuberosus). Turk Journal Chemistry, Istambul, v. 27, p. 217-225, 2003. 
